to advise and help students when any questions have arisen in regard to their health; the new scheme, however, by providing a simple form of machinery, will encourage students, whatever their present condition of health, to satisfy themselves of their physical fitness or be advised in good time of the measures they should take to become fit. Consideration is also being given by the authorities to the possibility of extending the facilities for physical training at the University. The students are naturally watching with keen interest these developments, which are taking place in consultation with the Union Committee.

\section{Agricultural Marketing Policy}

UNDER this head, Mr. A. N. Duckham, research officer to the Bacon Development Board, made a weighty contribution to the discussion on "State Intervention in Agriculture", which was held in Section M at the British Association meeting in Nottingham. In his view, recent marketing legislation is the offspring of the researches and inventions associated with the names of Liebig, Mendel, Faraday, Pasteur and others, and of the necessity for rectifying the imbalance between agriculture and manufacturing industries. The protective measures adopted by the marketing boards have helped to save British agriculture from chaos by reducing, through price stabilization, the speculative nature and insecurity of 40-50 per cent of home production, and by prompting improvements in agricultural business methods. Other beneficent activities of the boards have been the laying down of minimum quality standards the standardizing of trade practices, and the institution of good market-intelligence services. Equally important have been the provisions made for controlling competition, for example, by limiting the number of sugar-beet factories, creameries, bacon factories, potato merchants and cattle markets. The savings effected by cutting out surplus capacity and operating the remainder at full load should, it is stated, reduce the price spread between farmer and consumer ; and farmers should benefit by the practice of collective bargaining, which is one of the main objects of the Marketing Acts. A noteworthy feature of current policy is the statutory attempt to influence demand by 'consumption steering', that is, by means of differential prices and subsidies to consumers, by education, habit-changing and direct publicity. So far very little has been done in this direction, but, in the author's view, the success of current marketing policy will be largely governed by steering consumption more vigorously towards the produce of British soil. Planning and State intervention have come to stay, and their prospective effect will be to ensure stability of quality, supply and price.

\section{Development of the Glasshouse Industry}

A SERIES of papers delivered before Section M (Agriculture) of the British Association at Nottingham on September 6 dealt with the history and presentday practice of the growth of crops under glass. Mr. H. V. Taylor first indicated trends in the technique of plant forcing, from the early use of the cloche, through the employment of frames and greenhouses, to the modern Dutch lights and 'aeroplane' tomato houses. Dr. W. F. Bewley spoke upon "Science in Relation to the Glasshouse Industry". He showed how the increase in intensity of crop forcing, and the growth of produce out of its normal season, brings new problems of disease and of nutrition. Many examples of how these troubles have been overcome by the Cheshunt Research Station were given. Some of the investigations, as the work of Lloyd on control of the tomato moth caterpillar, and that of Speyer upon the control of white fly, are now classical, and the newer research maintains the high standard. A most welcome link with practice was provided by Mr. F. A. Secrett's paper on "The Production of Early Vegetables and Salads under Glass". The need for vegetables quickly grown on good soil, as a contribution to national health, was stressed. A suitable light soil, adequately manured, and a site with security of tenure and adequate water supply, are the first essentials. Heavy capital costs and labour charges are incurred, but Mr. Secrett's practical demonstra. tion of commercial success is even more eloquent than his illuminating paper.

\section{Fire-Immune Cable}

A FaCToRy, opened by Lord Ridley on October 12, for making fire-resisting cable called 'Pyrotenax', marks a new development which promises to be of far-reaching importance to the electrical industry. The insulating cover utilizes a new insulating material, magnesium oxide, the heat-resisting and other physical properties of which have been proved in connexion with boiling-plate elements, which are made of resistance wire embedded in the oxide. 'Pyrotenax' cable has a copper conductor, magnesia insulation, and copper sheath. The new technique enables continuous runs of this cable up to 300 yards to be produced. A piece of cable in series with a burning lamp can be hammered to the thickness of a sixpence without affecting the light. It is therefore mechanically robust. For all practical purposes the cable is immune from fire and would not contribute anything to a possible conflagration. Notable use has been made of 'Pyrotenax' cable in France. 'The Louvre, the Normandie, the Galeries Lafayette and the French railways use it. In Great Britain it has been adopted for the new lighting equipment of the Tate Gallery and for several industrial installations. The 'Pyrotenax' factory is practically 'all-electric' throughout, electric furnaces being used for all the annealing stages and for the dehydration of the magnesium oxide insulation. The rating of these furnaces is $\mathbf{2 5 0}$ kilowatts, and their temperature is controlled by a Cambridge thermostatic instrument. The factory is situated at Hedgely Road, Hebburnon-Tyne. A full illustrated account appeared in the Electrical Times of October 21.

\section{Electrical Accidents and their Causes}

IN a pamphlet issued by the Home Office (London : H.M. Stationery Office, 1937, 6d.) and written by H. W. Swann, H.M. Inspector of Factories, a report of electrical accidents for the year 1936 is given. The 